6. Oncofertility Consortium. Sickle Cell Anemia. Chicago, Northwestern University, 2014. Available online at http://oncofertility.northwestern.edu/ resources/sickle-cell-anemia.

7. Agbaraji VO, Scott RB, Leto S, Kingslow LW. Fertility studies in sickle cell disease: semen analysis in adult male patients. Int J Fertil 1988;33:347-352.
8. Abudu EK, Akanmu SA, Soriyan 00, Akinbami AA, Adediran A, Adeyemo TA, Okany CO. Serum testosterone levels of HbSS (sickle cell disease) male subjects in Lagos, Nigeria. BMC Res Notes 2011;4:298.

9. Gharwan H, Neary NM, Link M, Hsieh MM, Fitzhugh CD, Sherins RJ, Tisdale JF. Successful fertility restoration after allogeneic hematopoietic stem cell transplantation. Endocr Pract 2014;20:157-161.

\title{
Assessment of Quality of Life of Chronic Myeloid Leukemia Patients by Using the EORTC QLQ-C30
}

\section{Kronik Miyeloid Lösemili Hastaların Yaşam Kalitesinin EORTC QLQ-C30 Anketi Kullanılarak Değerlendirilmesi}

\author{
Mehmet Can Uğur ${ }^{1}$, Yaşar Bekir Kutbay², Özge Özer Kaya² ${ }^{2}$ Cengiz Ceylan³ \\ ${ }^{1}$ Tepecik Training and Research Hospital, Clinic of Internal Medicine, Izmir, Turkey \\ ${ }^{2}$ Tepecik Training and Research Hospital, Genetic Diagnostic Center, Izmir, Turkey \\ ${ }^{3}$ Tepecik Training and Research Hospital, Clinic of Hematology, Izmir, Turkey
}

To the Editor,

Depression is determined in 15\%-25\% of patients with cancer and it is accepted as a comorbid problem with poor prognosis. The quality of life of these patients is determined to be poor $[1,2]$. We aimed to study the quality of life of patients using new forms of imatinib, dasatinib, or nilotinib.

We analyzed 56 chronic myeloid leukemia patients followed in the İzmir Tepecik Training and Research Hospital Department of Hematology. Patients were followed from 2005 to 2015. We included patients who were $>18$ years of age, BCR-ABL-positive based on polymerase chain reaction results, using first- or second-generation tyrosine kinase inhibitors (TKIs) in the last 6 months, and in the chronic phase of the disease.

The Turkish version of the European Organisation for Research and Treatment of Cancer Quality of Life Questionnaire-C30 (EORTC OLQ-C30) [3], the Turkish version of the Hospital Anxiety and Depression Scale [4], and the General Health Questionnaire [5] were administered to patients one-on-one. The study received approval from the ethics committee.
The demographic data and laboratory values are provided in Table 1.

In our study, we found no statistical significance between firstand second-generation TKIs. We also compared dasatinib and nilotinib as subgroups of the second generation and we found statistical significance for dasatinib against nilotinib for general life quality, emotional and cognitive functions, and fatigue parameters.

Keywords: Cytogenetic, Chronic myeloid leukemia, Molecular hematology, Life-quality, Dasatinib, Nilotinib

Anahtar Sözcükler: Sitogenetik, Kronik miyeloid lösemi, Moleküler hematoloji, Yaşam kalitesi, Dasatinib, Nilotinib

Conflict of Interest: The authors of this paper have no conflicts of interest, including specific financial interests, relationships, and/or affiliations relevant to the subject matter or materials included. 
Table 1. Demographic datas, laboratory findings, follow up, Hospital Anxiety and Depression Scale, General Health

Questionnaire, Eastern Cooperative Oncology Group and Karnofsky scores, general medical, functional and symptom scales of European Organization for Research on Treatment of Cancer Questionnaires Quality of Life-C30 between $1^{\text {st }}$ generation tyrosine kinase inhibitor and $2^{\text {nd }}$ generation tyrosine kinase inhibitor (dasatinib and nilotinib).

\begin{tabular}{|c|c|c|c|c|c|c|}
\hline & 1. Generation & \multicolumn{2}{|c|}{ 2. Generation } & p value ${ }^{1}$ & Total & p value ${ }^{2}$ \\
\hline Age (year) & $56.7 \pm 1.2$ & $53.5 \pm 1.5$ & $57.7 \pm 1.5$ & 0.17 & $53.3 \pm 1.4$ & 0.29 \\
\hline \multicolumn{7}{|l|}{ Gender (n) } \\
\hline Male & 16 & 5 & 6 & & 11 & - \\
\hline Hemoglobin (g/dL) & $11.9 \pm 1.8$ & $11.5 \pm 1.5$ & $11.4 \pm 2.7$ & 0.40 & $11.3 \pm 1.9$ & 0.81 \\
\hline Platelet (/uL) & $298000 \pm 1.5$ & $212000 \pm 6.0$ & $342000 \pm 1.8$ & 0.33 & $287000 \pm 1.5$ & 0.71 \\
\hline Leukocyte (/uL) & $76050 \pm 1.1$ & $51300 \pm 9.0$ & $101000 \pm 7.5$ & 0.11 & $84080 \pm 8.0$ & 0.30 \\
\hline Follow up (month) & $57.2 \pm 34.6$ & $74.8 \pm 3.0$ & $61 \pm 2.5$ & 0.07 & $65.2 \pm 28.0$ & 0.15 \\
\hline HADs-A & $8 \pm 4.1$ & $8.6 \pm 4.1$ & $10.5 \pm 2.0$ & 0.18 & $8.3 \pm 4$ & 0.76 \\
\hline HADs-D & $5.8 \pm 4.1$ & $8.3 \pm 3.2$ & $10.5 \pm 4.2$ & 0.72 & $6.1 \pm 4.4$ & 0.86 \\
\hline $\mathrm{GHO}$ & $22.3 \pm 5.3$ & $20.6 \pm 2.0$ & $26.5 \pm 9.1$ & 0.08 & $23.2 \pm 6.1$ & 0.83 \\
\hline \multicolumn{7}{|c|}{ Scales of EORTC-QoL-C30 } \\
\hline General medical scale & $57.2 \pm 22.1$ & $68.1 \pm 18.1$ & $39.6 \pm 22.6$ & $0.016^{*}$ & $52.1 \pm 24.8$ & 0.95 \\
\hline \multicolumn{7}{|c|}{ Functional Scales of EORTC-QoL-C30 } \\
\hline Physical scale & $73.8 \pm 17.0$ & $81.4 \pm 2.2$ & $68 \pm 2.0$ & 0.142 & $73.9 \pm 21.4$ & 0.31 \\
\hline Role scale & $88.6 \pm 19.0$ & $98.2 \pm 4.7$ & $80.5 \pm 2.4$ & 0.252 & $88.2 \pm 20.1$ & 0.70 \\
\hline Fatique & $31.3 \pm 21.3$ & $19 \pm 1.3$ & $50.3 \pm 1.9$ & $0.005^{*}$ & $36.6 \pm 23.2$ & 0.67 \\
\hline Nausea & $13.5 \pm 19.5$ & $5.3 \pm 9.8$ & $9.7 \pm 1.6$ & 0.681 & $7.8 \pm 13.5$ & 0.21 \\
\hline Pain & $20.3 \pm 23.6$ & $10.7 \pm 1.3$ & $33.3 \pm 2.6$ & 0.114 & $24.3 \pm 24.0$ & 0.40 \\
\hline Dispnea & $11.4 \pm 19.0$ & $7.1 \pm 12.1$ & $25 \pm 33.0$ & 0.408 & $17.1 \pm 26.9$ & 0.11 \\
\hline Insomnia & $15.7 \pm 21.9$ & $7.1 \pm 12.1$ & $30.5 \pm 37$ & 0.351 & $20.3 \pm 30.5$ & 0.07 \\
\hline Loss of appetite & $13.9 \pm 17.6$ & $14.2 \pm 13.3$ & $22.2 \pm 23.1$ & 0.606 & $18.7 \pm 19.3$ & 0.75 \\
\hline Constipation & $12.1 \pm 17.5$ & $10.7 \pm 1.3$ & $30.5 \pm 2.4$ & 0.114 & $21.8 \pm 22.1$ & 0.58 \\
\hline Diarrhea & $10.7 \pm 22.1$ & $3.5 \pm 9.4$ & $16.6 \pm 2.1$ & 0.299 & $10.9 \pm 18.1$ & 0.83 \\
\hline Financial effect & $18.5 \pm 25.9$ & $14.2 \pm 2.8$ & $44.4 \pm 3.2$ & 0.091 & $31.2 \pm 33.5$ & 0.05 \\
\hline
\end{tabular}




\section{References}

1. Wilson $K G$, Chochinov $H M$, Shirko MG, Allard $P$, Chary $S$, Gagnon $P R$, Macmillan K, De Luca M, O'Shea F, Kuhl D, Fainsinger RL, Clinch JJ. Depression and anxiety disorders in palliative cancer care. J Pain Symptom Manage 2007;33:118-129.

2. Lloyd-Williams M, Friedman T. Depression in palliative care patients-a prospective study. Eur J Cancer Care (Engl) 2001;10:270-274.
3. Guzelant A, Goksel T, Ozkok S, Tasbakan S, Aysan T, Bottomley A. The European Organization for Research and Treatment of Cancer QLQ-C30: an examination into the cultural validity and reliability of the Turkish version of the EORTC OLOC30. Eur J Cancer Care Engl 2004;13:135-144.

4. Aydemir 0 . Validity and reliability of Turkish version of Hospital Anxiety and Depression scale. Turkish Journal of Psychiatry 1997;8:280-287.

5. Kilic C. General health questionnaire: a validity and reliability study. Turkish Journal of Psychiatry 1996;7:3-9.
口:她 $\square$ Address for Correspondence/Yazışma Adresi: Mehmet Can UĞUR, M.D.,

12 Tepecik Training and Research Hospital, Clinic of Internal Medicine, İmir, Turkey

Phone: +905058861126

E-mail : med.can@hotmail.com
Received/Geliş tarihi: October 18, 2016 Accepted/Kabul tarihi: December 22, 2016 